\title{
大学施設における削減可能なエネルギー消費量の推計と 双方向ユーザーインターフェースを有する「見える化システム」の開発 ESTIMATION OF AMOUNT OF ENERGY CONSUMPTION REDUCTION AT UNIVERSITY FACILITIES AND DEVELOPMENT OF “VISUALIZATION SYSTEM” WITH INTERACTIVE USER INTERFACE
}

\author{
魚住昌広*1, 半澤 久*2, 羽山広文*3 \\ Masahiro UOZUMI, Hisashi HANZAWA and Hirofumi HAYAMA
}

\begin{abstract}
This study shows a method to estimate the energy consumption reduction effect from data collected at "visualization system" at existing university facilities. Furthermore, we describe the development process of "interactive visualization system" that supports energy conservation behavior about energy conservation measures items extracted from the estimation of effect. The method of estimating the effect of reducing energy consumption can be apply to facilities of other uses. Development of a system that supports the operation of facilities can contribute to energy saving and low carbonization of existing facilities.
\end{abstract}

Keywords: Energy consumption, Campus buildings, Interactive interface, Visualization system エネルギー消費量, 大学施設, 双方向インターフェース, 見える化システム

\section{1. 研究背景と目的}

施設運用上の省エネルギーを推進寸るためには、エネルギー消費 の実態を把握し、運転管理方法の改善や具体的な省エネルギー行動 を策定し実行することが不可欠である。

大学施設においてもエネルギー消費の分析・評価の重要性は、強 く認識されている。永峯らは、東洋大学における調查研究から、キ ヤンパスのエネルギー消費量の管理基準值を得るための重回帰分析 による説明変数を求めている 1 。また、宋は、豊橋技術科学大学にお けるエネルギー消費量の実態調査研究により、理工系キャンパスの 空調用・非空調用エネルギー消費量の分離推定手法を示している 2)。 エネルギー消費の削減手法と効果の推計については、高野らが、 北海道大学における照明の点灯放置と制御による電力削減効果の推 計を行っている ${ }^{3)}$ 。大橋らは、大規模かつ分散型キャンパスである 大阪大学において、施設用途をカテゴリー区分し、それぞれのエネ ルギー消費特性を明らかにした上で 4)、生物科学系および情報工学 系研究施設における用途別エネルギー消費内訳の推計手法を示し、 エネルギー削減効果の定量化を行っている5)。また、河野らは、東 京大学におけるエネルギー消費実態の分析と環境負荷低減対策の検 討および高効率機器への更新や熱源の運用による対策の評価を行っ ている 6)。河村らは、中部大学において、ナビゲーション機能を有 する節電システムの導入効果による電力ピークの平準化と省エネル ギーによる多棟の既存建物の低炭素化を実証している 7,8)。
これらの既往研究におけるエネルギー消費量の推計の多くは、 キャンパス単位や学部・系等でグループ化した建築施設群を単位 として行われている。また、提示されているエネルギー削減手法 は、設備機器の高効率機器への転換、人感センサー等の制御機器 の設置、スマート BEMS の導入などによるものであり、改修工事 や設備機器の更新を伴う。既存施設においては、設備システムの 運用改善や利用者の行動による省エネルギー対策は実施されてい るが、対策の対象とする設備の選択方法や実施の効果について、 定量的に明らかにしたものは少ない。

北海道科学大学では、2009 年に Fig.1、Table1に示寸キャンパ ス内の全施設を対象に電力消費量、燃料消費量、代表室温度等を 計測・監視する「見える化システム」を導入した（Fig.11)〜12は、 Table1 の施設 No.を示す)。

「見える化システム」の導入以降、エネルギーの消費データを公 開し、施設管理者・教職員・学生ボランティアの協同による不要 な照明の消灯や冷暖房設備の設定温度を確認するためのパトロー ル、設置機器の省エネルギー設定を促寸各種のキャンペーンの実 施等、設備機器や制御機器の更新や追加に依存しない省エネルギ 一活動を行った。さらに、キャンパス内施設の全室の管理状況や 設置機器の使用実態の調查、教職員・学生への省エネルギー意識 や行動に関するアンケート調查を実施し、エネルギー消費量削減 の要因の抽出と各効果の定量的な評価を行った $9,10,11$ 。
*1 北海道科学大学工学部建築学科 准教授

*2 北海道科学大学工学部建築学科 名誉教授 · 博士 (工学)

*3 北海道大学大学院工学研究院 教授. 博士 (工学)
Assoc. Prof., Faculty of Eng., Hokkaido Univ. of Science

Prof. Emeritus, Faculty of Eng., Hokkaido Univ. of Science, Dr.Eng.

Prof., Faculty of Eng., Hokkaido Univ., Dr.Eng. 
「見える化システム」導入後の、キャンパス内全施設の年間エネル ギー消費量の推移を Fig.2 に示す。 2009 年以降、一次エネルギー換 算で 2010 年度は約 6\%、2011 年度は、約 10\%のエネルギーの削減 を達成した (注1)。エネルギー消費量の削減は、照明・コンセントの 単相負荷（以下「電灯負荷」）の削減による比重が大きく、「見える 化システム」を活用した省エネルギー行動によるエネルギー消費量 削減の実効性を実証した(12)。

しかし、「見える化システム」導入後 3 年を経過した 2012 年度で は、エネルギー消費量の減少傾向は鈍化した。既設の「見える化シ ステム」は、教職員・学生ともに大学のホームページ上でデータを 閲覧する方式であるが、システムのエンドユーザーにあたる教職員・ 学生に対するアンケート調査 ${ }^{(\text {注 } 2)}$ から、システムの認知度は向上し ているが、利用頻度は経年的に低下していることが明らかとなった。 これまでのエンドユーザーからのアクセスに依存する「受動的」な システムでは、今後、利用度の大幅な向上や、省エネルギー効果の 持続や向上を期待することは難しい。

「見える化システム」を施設の省エネルギー対策に有効活用する ためには、従来の「見える」機能に加え、システムからエンドユー ザーに対して、エネルギーの使用状況を「見せる」機能や有効な省 エネルギー行動を提示する「能動的」な機能が求められる。

本研究では、大学施設における持続的なエネルギー消費の削減手 法を示すことを目的とし、既設「見える化システム」の運用データ をもとに、削減可能なエネルギー消費量の推計手法を示し(第 2 章)、 削減効果の推計から省エネルギー対策項目を抽出し、施設運用モデ ルを構築した (第 3 章)。さらに、既設「見える化システム」の運用 で明らかとなった課題を解決するため、施設利用者や管理者に対し て、双方向のユーザーインターフェース機能を持つ省エネルギー支 援システム（以下「双方向システム」）の開発と評価（第 4 章）を行 った。

「双方向システム」は、施設利用者に対して有効な省エネルギー 行動を促すガイダンスメッセージを発信する機能を有し、施設管理 者に対しては、室内外温度などの環境条件・施設利用状況・設備機 器運転状況、利用者の温冷感などの主観的なユーザー情報を発信し、 適切な設備の運転管理を支援する機能を有するものである。

本報で示すエネルギー消費の削減効果の推計手法は、他用途の施 設へも展開が可能であり、施設運用・設備運転管理の支援を行うシ ステムの開発は、既存施設における省エネルギー・低炭素化に資す るものと考える。

\section{2. エネルギー消費削減可能量の推計}

\section{1 対象施設の概要}

「双方向システム」導入によるエネルギー消費削減効果を推計す るにあたっては、キャンパス施設群の中で、独立した冷暖房熱源を 持つ、「講義棟(Lecture Bldg.)」(Table1-No12) を対象施設として選 定した。「講義棟」の室用途別面積を Table 2 に示す。

当該施設における、「見える化システム」導入後の年間一次エネル ギー消費量の推移を Fig. 3 に示す。Fig. 2 に示すようにキャンパス 全施設のエネルギー消費量は、削減効果がみられたが、「講義棟」単 体では、電灯負荷に漸減の傾向はみられるものの、顕著な削減効果 は見られていない。

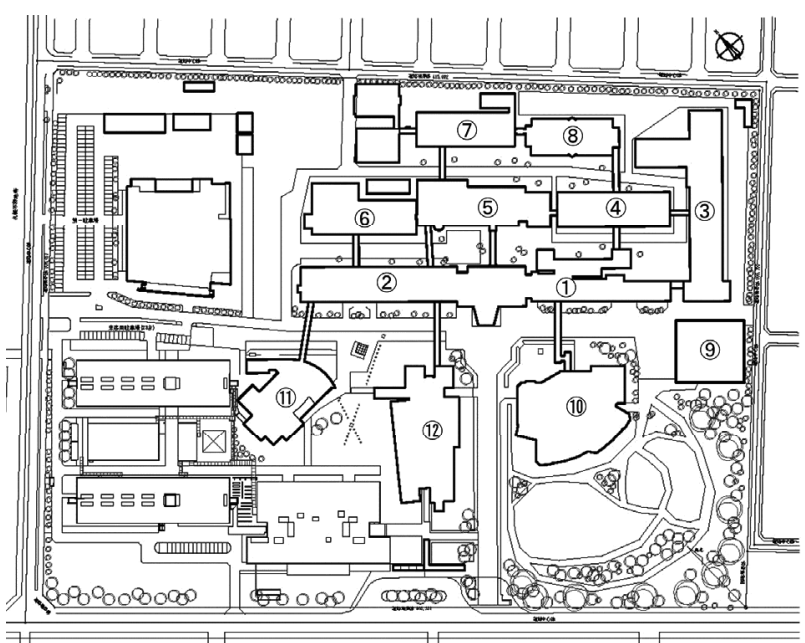

Fig.1 Layout of campus buildings

Table1 Name and total floor area of campus buildings

\begin{tabular}{|c|c|c|c|c|c|}
\hline No. & $\begin{array}{c}\text { Name } \\
\text { of } \\
\text { Facilities }\end{array}$ & Main Purpose Sections & Story & $\begin{array}{l}\text { Floor } \\
\text { Area } \\
{\left[\mathrm{m}^{2}\right]}\end{array}$ & $\begin{array}{l}\text { Completion } \\
\text { of } \\
\text { Construction }\end{array}$ \\
\hline 1 & 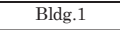 & $\begin{array}{l}\text { Office,Conference room,Faculty office } \\
\text {. }\end{array}$ & $3 \mathrm{~F}$ & 3,502 & 1967 \\
\hline 2 & \begin{tabular}{|l|l} 
Bldg.2 \\
\end{tabular} & Faculty office,Seminar room,Laboratory & $5 \mathrm{~F}$ & 9,405 & 1968 \\
\hline$\overline{3}$ & Bldg. 3 & Faculty office,Seminar room,Drawing room & $5 \mathrm{~F}$ & 8,497 & 1972 \\
\hline 4 & Bldg. 4 & Faculty office,Seminar room,Laboratory & $3 \mathrm{~F}$ & 3,589 & 1977 \\
\hline 5 & Bldg.5 & Lecture hall,Cafeteria,Server room & $3 \mathrm{~F}$ & 3,214 & 1977 \\
\hline 6 & Bldg.6 & Faculty office,Seminar room,Laboratory & $3 \mathrm{~F}$ & 3,503 & 1977 \\
\hline 7 & Bldg.7 & Faculty office,Seminar room,Laboratory & $3 \mathrm{~F}$ & 3,782 & 1985 \\
\hline 8 & Bldg.8 & Faculty office,Seminar room,Laboratory & $3 \mathrm{~F}$ & 2,649 & 1990 \\
\hline 9 & Gymnasium & Gymnasium,Martial art gym & $3 \mathrm{~F}$ & 2,460 & 1970 \\
\hline 10 & Library & Library,Reading room,Stack room & $2 \mathrm{~F}$ & 5,531 & 1986 \\
\hline 11 & HIT PLAZA & Cafeteria,School store,Office & $2 \mathrm{~F}$ & 2,197 & 1994 \\
\hline 12 & Lecture Bldg. & Lecture room,Office & $4 \mathrm{~F}$ & 9,396 & 2001 \\
\hline To & al Floor Area & & & 57,725 & \\
\hline
\end{tabular}

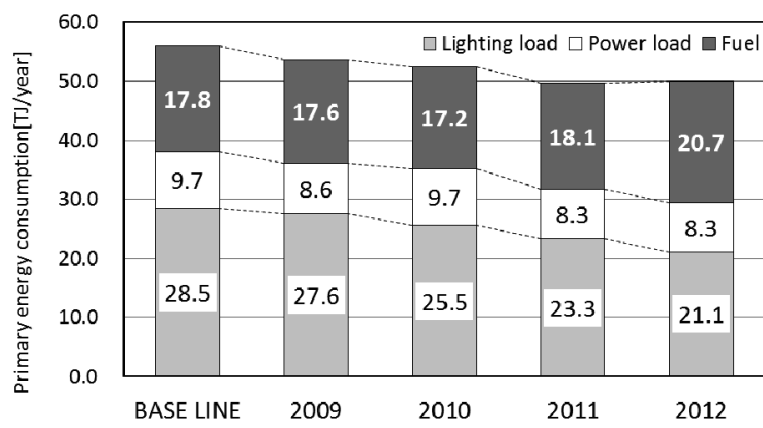

Fig.2 Annual primary energy consumption (All facilities)

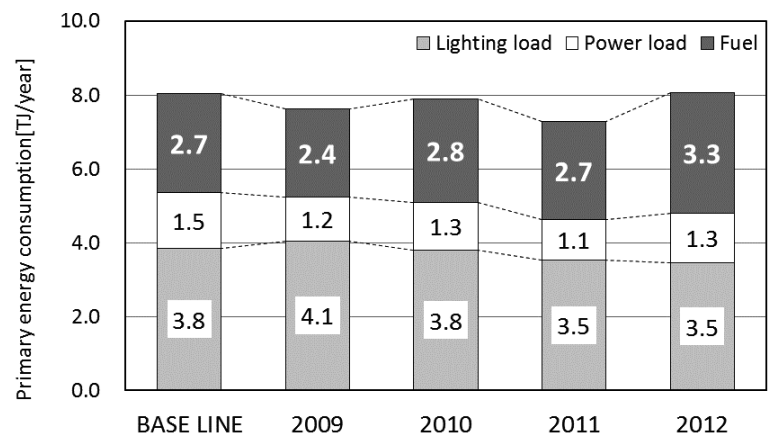

Fig.3 Annual primary energy consumption (Lecture Bldg.)

「講義棟」の主要空調用冷温熱源は、A 重油を燃料とする冷温 水発生機（冷暖房用熱源）と真空温水器（暖房用熱源）の併用で 
ある。「講義棟」熱源設備の運転状況については、既報 12)で、内外温 度差と燃料消費量との相関から、暖冷房負荷に応じて熱源設備が、 適切に運転管理されていることを検証している。

「講義棟」内の講義室の照明・換気設備をTable3 に示す。照明器 具は、天井埋込下面開放型蛍光灯 (灯具 FHF32)、換気機器は、各 室毎に複数台設置された全熱交換型換気扇である。いずれも各講義 室内のスイッチにより、教員もしくは学生が任意に操作可能である ことから、施設利用者の省エネルギー行動によるエネルギー消費の 削減が見込まれる。

\section{2 照明負荷の削減可能量の推計}

照明負荷の削減可能量は、消灯可能な時間帯の電力消費量から推 計した。2013 年度の開講期間（年間 30 週）の全ての日について、 各講義室の毎時電力消費量実測值と講義予定表、室使用記録から、 講義室単位で消灯可能な時間帯の電力消費量を集計した。Table4 に 一日単位の算出例を示す。講義室が開錠される $7: 00$ から 20：00 までの時間帯において、網掛けの時間帯は、各室の講義使用時間で あり、白抜きの時間帯は消灯可能な時間帯である。各講義室につい て、毎時消費電力量 $(\mathrm{A})$ 、日消費電力量 $(\mathrm{B}=\Sigma \mathrm{A})$ 、消灯可能な時間 帯の電力量 $(\mathrm{C})$ 、削減可能な電力量比率 $(\mathrm{C} / \mathrm{B})$ を求めた。

上記の手法によって推計した、2013 年度の照明負荷分の削減可能 な年間電力量を Table5 (E1) に示す。表中の用途別電力消費量 (a1: 動力負荷 $(3 \phi-200 \mathrm{~V}) 、 \mathrm{a} 2$ : コンセント負荷 $(1 \phi-100 \mathrm{~V}) 、 \mathrm{a} 3$ : 照明 負荷 $(1 \phi-100 \mathrm{~V}))$ は当該年度の実績值である。

講義棟の推計削減可能電力量は $20,150 \mathrm{kWh} /$ 年となり、年間電力 消費量の $4.1 \%$ を占める。

\section{3 換気負荷の削減可能量の推計}

講義室照明が点灯放置されている時間帯は、換気設備も稼働した ままと仮定し、前節と同様の方法を用いて、換気負荷の削減可能量 を推計した。換気 (外気) 負荷に相当する削減可能な燃料消費量は、 各室毎に時刻毎の、外気と室内空気のエンタルピー差に換気風量を 乗じて算出した。Table5（E2）に削減可能な全熱交換型換気扇分の 年間電力量、Table6 に削減可能な年間燃料消費量を示寸 (注3)。

削減可能な換気負荷相当分の年間エネルギー消費量は、講義棟年 間燃料消費量の $2.4 \%$ (燃料消費量換算 : 2,121 l/年) であり、削減 可能な年間電力量は、 $14,661 \mathrm{kWh} /$ 年、講義棟年間電力消費量の $3.0 \%$ となった。

\section{4 調光設備の利用による電力削減可能量の推計}

講義室照明には、昼光センサーを用いた自動調光設備を設置して いる。講義室の机上面照度は、昼光の無い時間帯（夜間）において

Table5 Reducible Power Consumption of Lighting/Ventilation Load(Lecture Bldg.)

\begin{tabular}{c|l|c|r|l}
\hline No & \multicolumn{1}{|c|}{ Load classification } & Unit & $\begin{array}{c}\text { Annual } \\
\text { Power } \\
\text { Consumption }\end{array}$ & $\begin{array}{c}\text { Ratio of } \\
\text { reducible energy }\end{array}$ \\
\hline $\mathrm{A}$ & Total Power Consumption & $\mathrm{kWh} / \mathrm{Y}$ & 496,421 & $\mathrm{~A}=\mathrm{a} 1+\mathrm{a} 2+\mathrm{a} 3$ \\
\hline $\mathrm{a} 1$ & Power Load & $\mathrm{kWh} / \mathrm{Y}$ & 133,452 & \\
\hline $\mathrm{a} 2$ & Outlet Load & $\mathrm{kWh} / \mathrm{Y}$ & 53,309 & \\
\hline $\mathrm{a} 3$ & Lighting Load & $\mathrm{kWh} / \mathrm{Y}$ & 309,661 & \\
\hline $\mathrm{E} 1$ & $\begin{array}{l}\text { Reducible Power Consumption } \\
\text { (Lighting Load) }\end{array}$ & $\mathrm{kWh} / \mathrm{Y}$ & 20,150 & $\mathrm{E} 1 / \mathrm{A}=4.1 \%$ \\
\hline $\mathrm{E} 2$ & $\begin{array}{l}\text { Reducible Power Consumption } \\
\text { (Ventilation Load) }\end{array}$ & $\mathrm{kWh} / \mathrm{Y}$ & 14,661 & $\mathrm{E} 2 / \mathrm{A}=3.0 \%$ \\
\hline $\mathrm{E} 3$ & $\begin{array}{l}\text { Reducible Power Consumption } \\
\text { (By use of dimming equipment) }\end{array}$ & $\mathrm{kWh} / \mathrm{Y}$ & 2,481 & $\mathrm{E} 3 / \mathrm{A}=0.5 \%$ \\
\hline$\Sigma \mathrm{E}$ & Total Reducible Power Consumption & $\mathrm{kWh} / \mathrm{Y}$ & 37,292 & $(\mathrm{E} 1+\mathrm{E} 2+\mathrm{E} 3) / \mathrm{A}=7.5 \%$ \\
\hline
\end{tabular}

Table2 Table of area (Lecture Bldg.)

\begin{tabular}{l|c|c|r|l}
\hline Room usage & $\begin{array}{c}\text { Number } \\
\text { of rooms }\end{array}$ & Floor & $\begin{array}{c}\text { Floor area } \\
(\mathrm{m} 2)\end{array}$ & Notes \\
\hline Lecture room & 29 & $1 \sim 4$ & 4,533 & \\
\hline Locker room & 12 & $1 \sim 4$ & 322 & \\
\hline Office & 8 & 1 & 352 & \\
\hline Stock room & 2 & 1 & 80 & \\
\hline Machine room & 1 & 1 & 138 & \\
\hline Other & & $1 \sim 4$ & 3,971 & Hallway,WC,etc \\
\hline Total & & & 9,396 & \\
\hline
\end{tabular}

Table3 Lighting/Ventilation equipment(Lecture Bldg.)

\begin{tabular}{|c|c|c|c|c|c|c|c|c|c|c|c|}
\hline \multirow{3}{*}{ No } & \multirow{3}{*}{$\begin{array}{l}0 \\
\frac{0}{I I}\end{array}$} & \multirow{3}{*}{$\begin{array}{c}\text { Room } \\
\text { No. }\end{array}$} & \multirow[b]{2}{*}{ Area } & \multirow[b]{2}{*}{$\begin{array}{c}\text { Seating } \\
\text { Capacity }\end{array}$} & \multicolumn{2}{|c|}{ Lighting equipment } & \multicolumn{5}{|c|}{ Heat-exchange ventilation fan } \\
\hline & & & & & $\begin{array}{c}\text { Number } \\
\text { of } \\
\text { equip } \\
\text { ment }\end{array}$ & \begin{tabular}{|c|} 
Power \\
consump \\
tion
\end{tabular} & \begin{tabular}{|c|} 
Rated \\
Air \\
Volume
\end{tabular} & $\begin{array}{c}\text { Power } \\
\text { consump } \\
\text { tion }\end{array}$ & $\begin{array}{c}\text { Number } \\
\text { of } \\
\text { fan }\end{array}$ & $\begin{array}{c}\text { ventilation } \\
\text { Air } \\
\text { Volume }\end{array}$ & $\begin{array}{c}\text { Power } \\
\text { consump } \\
\text { tion }\end{array}$ \\
\hline & & & $\mathrm{m} 2$ & /Room & /Room & $\begin{array}{c}\text { Wh } \\
\text { /Room }\end{array}$ & $\begin{array}{c}\mathrm{m} 3 / \mathrm{h} \\
/ \text { fan }\end{array}$ & $\begin{array}{l}\mathrm{W} \\
\text { /fan }\end{array}$ & /Room & $\begin{array}{c}\mathrm{m3} / \mathrm{h} \\
/ \text { Room }\end{array}$ & $\begin{array}{c}\text { Wh } \\
\text { /Room }\end{array}$ \\
\hline 1 & 1 & G101 & 146 & 96 & 76 & 3,420 & 670 & 325 & 3 & 2,010 & 975 \\
\hline 2 & 1 & G102 & 147 & 96 & 76 & 3,420 & 670 & 325 & 3 & 2,010 & 975 \\
\hline 3 & 1 & G103 & 218 & 160 & 133 & 5,985 & 870 & 435 & 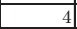 & 3,480 & 1,740 \\
\hline 4 & 1 & G104 & 215 & 187 & 133 & 5,985 & 870 & 435 & 4 & 3,480 & 1,740 \\
\hline 5 & 1 & G108 & 137 & 84 & 70 & 3,150 & 670 & 325 & 3 & 2,010 & 975 \\
\hline 6 & 2 & G201 & 146 & 96 & 70 & 3,150 & 670 & 325 & 3 & 2,010 & 975 \\
\hline 7 & 2 & G202 & 147 & 96 & 70 & 3,150 & 670 & 325 & 3 & 2,010 & 975 \\
\hline 8 & 2 & G203 & 218 & 160 & 97 & 4,365 & 870 & 435 & 4 & 3,480 & 1,740 \\
\hline 9 & 2 & G204 & 215 & 187 & 97 & 4,365 & 870 & 435 & , & 3,480 & 1,740 \\
\hline 10 & 2 & G205 & 142 & 84 & 70 & 3,150 & 670 & 325 & 3 & 2,010 & 975 \\
\hline 11 & 2 & G206 & 137 & 84 & 70 & 3,150 & 670 & 325 & 3 & 2,010 & 975 \\
\hline 12 & 22 & \begin{tabular}{|l|} 
G207 \\
\end{tabular} & 137 & 84 & 70 & 3,150 & 670 & 325 & 3 & 2,010 & 975 \\
\hline 13 & 2 2 & G209 & 137 & 84 & 70 & 3,150 & 670 & 325 & 3 & 2,010 & 975 \\
\hline 14 & 3 & G301 & 146 & 96 & 70 & 3,150 & 670 & 325 & 3 & 2,010 & 975 \\
\hline 15 & \begin{tabular}{l|l}
3 & \\
\end{tabular} & G303 & 218 & 160 & 97 & 4,365 & 870 & 435 & 4 & 3,480 & 1,740 \\
\hline 16 & \begin{tabular}{l|l}
3 & \\
\end{tabular} & G304 & 215 & 187 & 97 & 4,365 & 870 & 435 & 4 & 3,480 & 1,740 \\
\hline 17 & \begin{tabular}{l|l}
3 & $(1$ \\
\end{tabular} & G305 & 142 & 84 & 70 & 3,150 & 670 & 325 & 3 & 2,010 & 975 \\
\hline 18 & \begin{tabular}{l|l}
3 & \\
\end{tabular} & G306 & 137 & 84 & 70 & 3,150 & 670 & 325 & 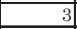 & 2,010 & 975 \\
\hline 19 & \begin{tabular}{l|l}
3 & \\
\end{tabular} & G307 & 137 & 84 & 70 & 3,150 & 670 & 325 & 3 & 2,010 & 975 \\
\hline 20 & \begin{tabular}{|c|}
3 \\
\end{tabular} & G308 & 137 & 84 & 70 & 3,150 & 670 & 325 & 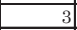 & 2,010 & 975 \\
\hline 21 & \begin{tabular}{l|l}
3 & \\
\end{tabular} & \begin{tabular}{|l|} 
G309 \\
\end{tabular} & 137 & 84 & 70 & 3,150 & 670 & 325 & 3 & 2,010 & 975 \\
\hline 22 & \begin{tabular}{l|l}
4 \\
\end{tabular} & G401 & 146 & 96 & 70 & 3,150 & 670 & 325 & 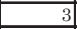 & 2,010 & 975 \\
\hline 23 & \begin{tabular}{l|l}
4 & \\
\end{tabular} & G402 & 146 & 96 & 70 & 3,150 & 670 & 325 & 3 & 2,010 & 975 \\
\hline 24 & \begin{tabular}{l|l}
4 & \\
4
\end{tabular} & G403 & 127 & 84 & 70 & 3,150 & 670 & 325 & 3 & 2,010 & 975 \\
\hline 25 & 4 & G404 & 140 & 84 & 70 & 3,150 & 670 & 325 & 3 & 2,010 & 975 \\
\hline 26 & \begin{tabular}{l|l}
4 & \\
\end{tabular} & G405 & 142 & 84 & 70 & 3,150 & 670 & 325 & 3 & 2,010 & 975 \\
\hline 27 & \begin{tabular}{l|l}
4 & \\
\end{tabular} & G406 & 137 & 84 & 70 & 3,150 & 670 & 325 & 3 & 2,010 & 975 \\
\hline 28 & \begin{tabular}{l|l}
4 & \\
\end{tabular} & G407 & 137 & 84 & 70 & 3,150 & 670 & 325 & 3 & 2,010 & 975 \\
\hline 29 & \begin{tabular}{l|l}
4 & \\
\end{tabular} & G408 & 141 & 84 & 70 & 3,150 & 670 & 325 & 3 & 2,010 & 975 \\
\hline & Total & & 4,533 & \begin{tabular}{|c|}
3,057 \\
\end{tabular} & 2,276 & 102,420 & & & $\begin{array}{ll}93 \\
\end{array}$ & 67,110 & 32,865 \\
\hline
\end{tabular}

Table4 Calculation example of Reducible Power Consumption(Lecture Bldg.)

\begin{tabular}{|c|c|c|c|c|c|c|c|c|c|c|c|}
\hline & \multirow{2}{*}{$\begin{array}{c}2013 / 4 / 15 \\
\text { MON }\end{array}$} & \multirow{2}{*}{ TIME } & \multicolumn{8}{|c|}{ Room NO. } & \multirow{2}{*}{ Total } \\
\hline & & & G201 & G202 & G203 & G204 & G205 & G206 & G207 & G209 & \\
\hline \multirow{14}{*}{ A } & \multirow{14}{*}{$\begin{array}{c}\text { Hourly Power } \\
\text { Consumption } \\
(\mathrm{kWh} / \mathrm{h})\end{array}$} & $7: 00$ & 0.0 & 0.0 & 0.0 & 0.0 & 0.0 & 0.0 & 0.0 & 0.0 & 0.0 \\
\hline & & $8: 00$ & 0.0 & 0.0 & 0.0 & 0.0 & 0.0 & 0.0 & 0.4 & 0.0 & 0.4 \\
\hline & & 9:00 & 0.3 & 0.1 & 2.0 & 0.2 & 0.3 & 1.3 & 1.3 & 0.2 & 5.7 \\
\hline & & 10:00 & 1.2 & 1.4 & 2.4 & 1.0 & 0.2 & 2.4 & 1.8 & 2.5 & 12.9 \\
\hline & & 11:00 & 1.2 & 1.4 & 2.1 & 2.4 & 1.5 & 2.1 & 1.7 & 2.4 & 14.8 \\
\hline & & $12: 00$ & 1.5 & 1.6 & 1.8 & 2.4 & 1.2 & 2.2 & 1.8 & 2.5 & 15.0 \\
\hline & & 13:00 & 0.5 & 1.8 & 1.9 & 2.4 & 1.8 & 2.4 & 1.7 & 2.4 & 14.9 \\
\hline & & $14: 00$ & 1.2 & 1.8 & 1.3 & 2.4 & 1.2 & 1.5 & 1.7 & 2.5 & 13.6 \\
\hline & & 15:00 & 1.3 & 1.8 & 2.4 & 2.9 & 1.3 & 1.9 & 1.5 & 1.8 & $\begin{array}{l}14.9 \\
\end{array}$ \\
\hline & & $16: 00$ & 1.8 & 1.8 & 0.8 & 2.9 & 1.6 & 3.0 & 1.1 & 2.4 & 15.4 \\
\hline & & 17:00 & 0.6 & 0.6 & 2.0 & 1.5 & 1.3 & 2.6 & 0.0 & 1.3 & 9.9 \\
\hline & & $18: 00$ & 0.0 & 0.6 & 2.4 & 1.6 & 0.4 & 1.9 & 0.0 & 0.0 & 6.9 \\
\hline & & 19:00 & 0.0 & 1.1 & 0.2 & 0.0 & 0.0 & 1.2 & 0.0 & 0.0 & 2.5 \\
\hline & & $20: 00$ & 0.0 & 0.0 & 0.0 & 0.0 & 0.0 & 0.5 & 0.0 & 0.0 & 0.5 \\
\hline B & $\begin{array}{l}\text { Daily Power } \\
\text { Consumption }\end{array}$ & (kWh/day) & 9.6 & 14.0 & 19.3 & 19.7 & 10.8 & 23.0 & 13.0 & 18.0 & 127.4 \\
\hline C & $\begin{array}{l}\text { Reducible } \\
\text { Power Consumption }\end{array}$ & (kWh/day) & 2.3 & 5.9 & 0.2 & 3.1 & 2.9 & 6.6 & 3.8 & 5.5 & 30.3 \\
\hline D & $\begin{array}{l}\text { Reduction Rate } \\
(\mathrm{D}=\mathrm{C} / \mathrm{B})\end{array}$ & $(\%)$ & $24 \%$ & $42 \%$ & $1 \%$ & $16 \%$ & $27 \%$ & $29 \%$ & $29 \%$ & $31 \%$ & $24 \%$ \\
\hline
\end{tabular}

Table6 Reducible Fuel Consumption of Ventilation Load(Lecture BIdg.)

\begin{tabular}{c|l|c|r|l}
\hline No & \multicolumn{1}{|c|}{ Load classification } & Unit & Consumption & $\begin{array}{c}\text { Ratio of } \\
\text { reducible energy }\end{array}$ \\
\hline a & Fuel consumption & $\ell / Y$ & 86,932 & \\
\hline b & Heat generation (by fuel) & $\mathrm{MJ} / \mathrm{Y}$ & $2,549,281$ & \\
\hline $\mathrm{c}$ & Reducible Heat generation & $\mathrm{MJ} / \mathrm{Y}$ & 62,201 & $\mathrm{c} / \mathrm{b}=2.4 \%$ \\
\hline
\end{tabular}


定格消費電力の $80 \%$ で確保されるため、定格消費電力の $80 \%$ を超過 した照明用電力量は、調光設備の適切な使用によって、削減可能と 考えられる。調光設備による削減可能電力量 (Table5 (E3)) は、 $2,481 \mathrm{kWh} /$ 年となり、講義棟年間電力消費量の $0.5 \%$ となった。 $2.2 \sim 2.4$ 節より、「講義棟」の削減可能なエネルギー消費量は、 2013 年度の実績値に対して、年間消費電力消費量の $7.5 \%$ (照明電 力分 $4.1 \%$ +換気動力分 $3.0 \%$ +調光分 $0.5 \%$ ) 、換気負荷の削減によ る削減可能な年間燃料消費量は $2.4 \%$ と推計され、利用者の省エネ ルギー行動によるエネルギー消費量の削減の可能性を示唆している。

\section{3. 施設運用モデルの構築}

「双方向システム」の導入対象施設とした「講義棟」の省エネル ギー対策項目を抽出するため、既設の「見える化システム」で収集 したデータおよび既往の管理日月報などの運転管理記録の分析、施 設管理者へのヒアリング等を行い、施設運用のモデル化を行った。

モデル化にあたって、情報の受発信者（ユーザー）、操作対象とす る室・設備種目、操作対象機器を以下(1)〜 (3)に区分した。

(1)対象者 : 教職員・学生・施設管理者

(2)対象室 (設備)：講義室・熱源設備・電力設備

(3)対象機器 : 照明器具 $\cdot$ 調光設備 - 冷暖房機器 - 換気機器 - 熱源 機器・空調機、床暖房設備

さらに、対象室や設備ごとに、使用（運用）状況から、主要用途 室である講義室の「照明・換気・調光・冷暖房」設備、全館の「熱 源設備・外調設備・アトリウム暖房設備」および「電力設備」につ いて、相互の関係と情報の発信の要否を判定するデータ項目、判定 間隔、操作内容をまとめたものを「ユースケース」として区分した

(Table7)。

講義室を対象とした[ユースケース 1-1～1-4]は教職員・学生一、 共用部および全館を対象とした[ユースケース 2-1〜2-3]、[ユースケ ース 3]は施設管理者に対して情報発信を行うものとする。

情報発信の要否判定に必要なデータ(以下、「判定データ」)、およ び情報発信の要否判定基準(閾值)（以下「判定基準值」）として用い るデータを以下に示す。また、講義室のユースケース分析シートを Table8 に、省エネルギー対策項目とガイダンスメッセージ、発信間 隔を Table9 に示す。

[共通データ]（全ユースケースに共通して必要なデータ）

・講義棟（講義室）使用スケジュール

(開放教室・自習室の使用スケジュールを含む。)

[ユースケース : 1-1 1-3] : 講義室設備 $\left(\right.$ 照明・換気 ${ }^{(\text {注4) }}$ ・調光設備)

・判定データ : 照明電力消費量

- 判定基準値 : 照明電力量基準值(全点灯時 - 調光時)

[ユースケース : 1-4]：講義室設備（冷暖房設備）

・判定データ : 室内温度、利用者温冷感申告

- 判定基準值 : 室内温度基準值、利用者温冷感申告（比率）

[ユースケース : 2-1] : 熱源設備

- 判定データ : 外気温度、熱源運転状態、熱源製造熱量、利用者 温冷感申告

- 判定基準值 : 外気温度基準值、熱源製造熱量基準值、利用者温 泠感 (比率)

[ユースケース : 2-2] : 外調設備
・判定データ : 共用部温湿度、外調機運転状態

- 判定基準值 : 共用部温湿度基準值

[ユースケース : 2-3] : 暖房設備（アトリウム床暖房・FCU : 冬期 $)$

・判定データ : アトリウム温度、 FCU 運転状態

・判定基準值 : アトリウム温度基準值

[ユースケース：3]：電力設備

・判定データ : 講義棟全電力消費量

• 判定基準值 : 講義棟電力消費量基準値

Table7 Classification of USE-CASE

\begin{tabular}{c|l|l|l}
\hline No. & \multicolumn{1}{|c|}{ Facilities / rooms } & \multicolumn{1}{c|}{ Facility item } & Recipient of operation information \\
\hline $1-1$ & Lecture Room & Lighting equipment & Faculty staff/Students \\
\hline $1-2$ & $\prime \prime$ & Ventilation fan & " \\
\hline $1-3$ & $\prime \prime$ & Dimming system & " \\
\hline $1-4$ & $\prime \prime$ & Fan coil unit & " \\
\hline $2-1$ & Heat source equipment & Chiller/Boiler & Facility manager/Staff \\
\hline $2-2$ & Ventilating facilities & Air handling unit & $"$ \\
\hline $2-3$ & Heating equipment & Fan coil unit & $" \prime$ \\
\hline 3 & Power equipment & Demand control & $"$ \\
\hline
\end{tabular}

Table8 USE-CASE Analysis sheet(Lecture Room)

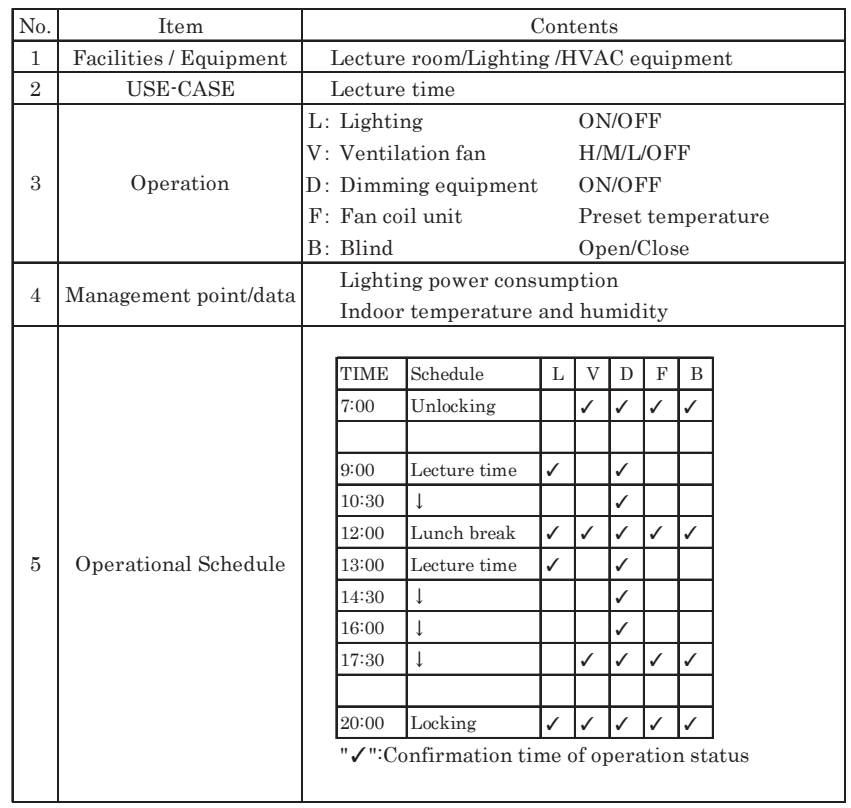

Table9 Energy saving points/Guidance contents

$\diamond$ Energy saving points

Turn off lights at non-use time

Use dimming equipment

Effective use of blinds (due to seasons and weather)

Check preset temperature

Effective use of heat exchange ventilation fan

$\diamond$ Guidance contents

Target: Faculty / Student

Content of guidance:

ex."Please use Dimming equipment."

"Please turn off the lights."

"Please check the use condition of the blind."

"Please check the setting temperature."

("Standard preset temperature is \#\# ${ }^{\circ} \mathrm{C} . "$ )

$\diamond$ Check time : 9: 00,12:00,13:00 (3 times / day) 


\section{4. 双方向ユーザーインターフェースの開発と評価}

\section{1 情報発信フローの作成}

「双方向システム」は、従来の「見える化システム」の有するデ ータ閲覧機能に加えて、システムとユーザー間の双方向インターフ エースを有するものとして開発した。

「双方向システム」は、室内外温湿度、機器の運転状況、エネル ギー消費量等の計測一次データおよび演算によって導出した二次デ ータに加え、ユーザーの温冷感情報を受信し、教職員・学生に対し ては、省エネルギー行動のガイダンスメッセージを、施設管理者へ は設備運転の補助となる情報を発信する。

前章のユースケースの分析をもとに、講義室設備（照明・換気・ 調光 ・ 冷暖房)、熱源設備・外調設備・アトリウム暖房設備、電力設 備についてプログラム作成のための「情報発信フロー」を作成した。

施設管理者を対象とした暖房期の熱源設備の運用に関する「情報 発信フロー」を Fig4 に示す。熱源機器 $(\mathrm{BH}, \mathrm{RH})$ の ON-OFF は、 運転状態を示寸。また、判定基準としている外気温度 $(\mathrm{t} 0)$ 、熱源製 造熱量 $(\mathrm{QW})$ は、既往の施設運転管理記録から設定した。また、温 冷感申告は施設利用者 (学生) スマートフォンからの申告（比率） による。これらの判定基準值は、運用実態に応じて、設定の変更を 可能としている。

「情報発信フロー」の判定に基づく、ガイダンス内容を Table10 に示す。対象設備の操作に関するガイダンスメッセージは、施設管 理者と同時に教職員・学生へ発信される。

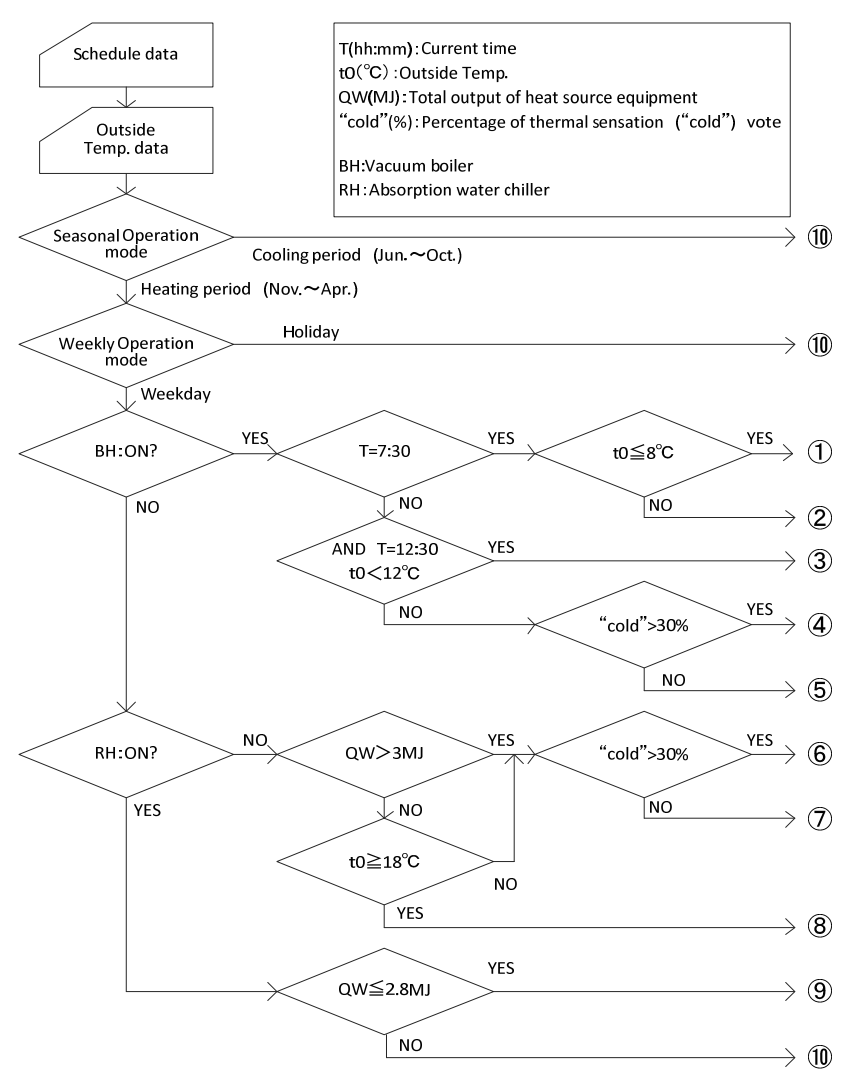

Fig.4 Disseminate information flow (Heat source equipment)

\section{2 双方向ユーザーインターフェースシステム}

\section{2.1 システムの構成}

「双方向システム」のインターフェースシステムの構成を Fig.5 に示す。本システムは、ハードウェアとして、インターフェース サーバー、メールサーバー、各種センサー、データロガーから構 成しており、施設利用者 (教職員・学生) や設備運転管理者の操 作性を考慮し端末のインターフェースは、スマートフォン、ユー ザーPCとした。

また、一般の施設利用者に常時情報公開を行うため、ユーザー $\mathrm{PC}$ 画面と同じ内容を表示し、任意に画面操作の可能なインタラ クティブディスプレイをパブリックスペースに配置した。

\subsection{2 双方向システムの機能}

各機能概要と動作仕様を以下 1）～6）に、画面表示例を Fig.6 に示す。なお本システムの各種判定プログラムはスクリプト記述 としており、「情報発信フロー」と参照する判定基準值などが明示 され、改良・変更が容易なものとしている。

1）計測データ収集機能

2) データ処理・集計機能

Table10 Guidance list by condition judgment (Heat source equipment)

\begin{tabular}{|c|c|c|c|}
\hline No. & Guidance message & Control/Operation & \\
\hline \multirow{2}{*}{ (1) } & \multirow{2}{*}{$\begin{array}{l}\text { "It's cold today. } \\
\text { Please start heating } \\
\text { operation." }\end{array}$} & $\begin{array}{l}\Rightarrow \text { Heat source: ON } \\
\quad<\text { Vacuum boiler }>\end{array}$ & ON \\
\hline & & $\begin{array}{c}\text { Guidance for Faculty/Students) } \\
\quad<\text { Window }> \\
<\text { Heat exchange ventilator }>\end{array}$ & $\begin{array}{c}\text { Close } \\
\text { ON }\end{array}$ \\
\hline (2) & $\begin{array}{l}\text { "Heating operation is not } \\
\text { necessary." }\end{array}$ & - & \\
\hline \multirow{2}{*}{ (3) } & \multirow{2}{*}{$\begin{array}{l}\text { "Outside temperature is } \\
\#^{\circ} \mathrm{C} \text {. } \\
\text { Check the user information } \\
\text { Please judge heating } \\
\text { operation." }\end{array}$} & $\begin{array}{c}\Rightarrow \text { Heat source: ON } \\
\quad \text { <Vacuum boiler }> \\
\text { <Atrium FCU> }\end{array}$ & $\begin{array}{l}\text { ON } \\
\text { ON }\end{array}$ \\
\hline & & $\begin{array}{c}\text { Guidance for Faculty/Students) } \\
\quad<\text { Window }> \\
<\text { Heat exchange ventilator }> \\
\end{array}$ & $\begin{array}{c}\text { Close } \\
\text { ON }\end{array}$ \\
\hline \multirow[t]{2}{*}{ (4) } & \multirow{2}{*}{$\begin{array}{l}\text { "Lecture room seems to be } \\
\text { cold. } \\
\text { Check the user information. } \\
\text { Please judge heating } \\
\text { operation." }\end{array}$} & $\begin{array}{c}\Rightarrow \text { Heat source: ON } \\
\quad \text { <Vacuum boiler }> \\
\quad \text { <Atrium FCU> }\end{array}$ & $\begin{array}{l}\text { ON } \\
\text { ON }\end{array}$ \\
\hline & & \begin{tabular}{|c|} 
Guidance for Faculty/Students) \\
$\quad<$ Window $>$ \\
$<$ Heat exchange ventilator $>$ \\
\end{tabular} & $\begin{array}{c}\text { Close } \\
\text { ON }\end{array}$ \\
\hline (5) & (No guidance) & - & \\
\hline (6) & $\begin{array}{l}\text { "Heat output < Heat Load. } \\
\text { Please judge } \mathrm{RH}(\text { No.2) } \\
\text { opereation." }\end{array}$ & $\begin{aligned} \Rightarrow & \text { Heat source: ON } \\
& <\text { Absorption water chiller }>\end{aligned}$ & ON \\
\hline (7) & (No guidance) & - & \\
\hline \multirow{2}{*}{ (8) } & \multirow{2}{*}{$\begin{array}{l}\text { "It's warm today. } \\
\text { Please stop heating } \\
\text { operation." }\end{array}$} & $\begin{array}{c}\Rightarrow \text { Heat source: OFF } \\
\quad<\text { Vacuum boiler }> \\
\text { <Atrium FCU> }\end{array}$ & $\begin{array}{l}\text { OFF } \\
\text { OFF }\end{array}$ \\
\hline & & \begin{tabular}{|c|} 
Guidance for Faculty/Students) \\
$\quad<$ Window $>$ \\
$<$ Heat exchange ventilator $>$
\end{tabular} & $\overline{\mathrm{ON}}$ \\
\hline (9) & $\begin{array}{l}\text { "Heat output } \geqq \text { Heat Load. } \\
\text { Please stop } \mathrm{RH}(\text { No.2) } \\
\text { opereation." }\end{array}$ & $\begin{array}{l}\Rightarrow \text { Heat source: ON } \\
\quad<\text { Absorption water chiller }>\end{array}$ & OFF \\
\hline (10) & (No guidance) & - & \\
\hline
\end{tabular}

$\Rightarrow$ : Judgment of heat source (group control) operation $\langle>$ :Operation target equipment 


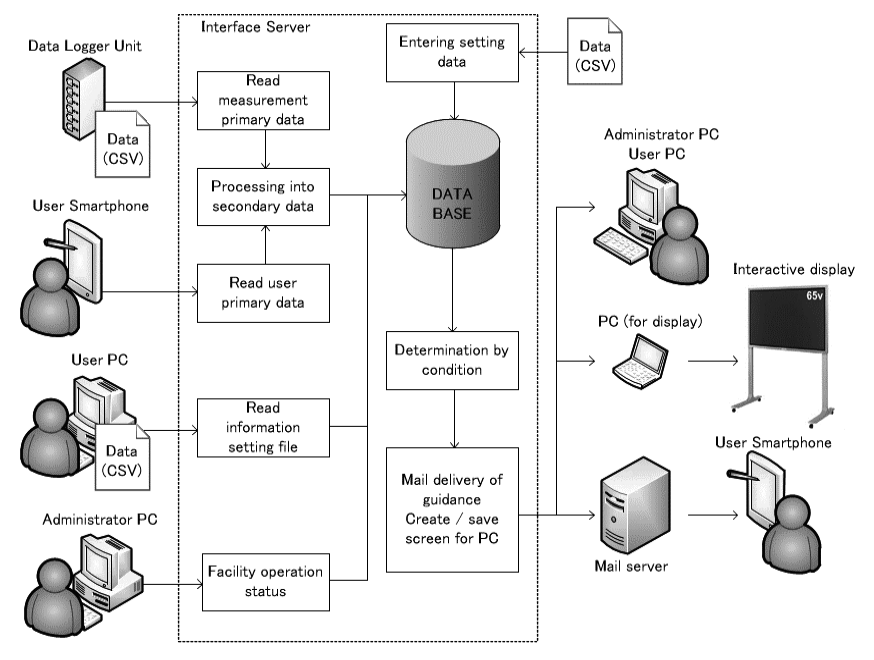

Fig.5 Interface system configuration

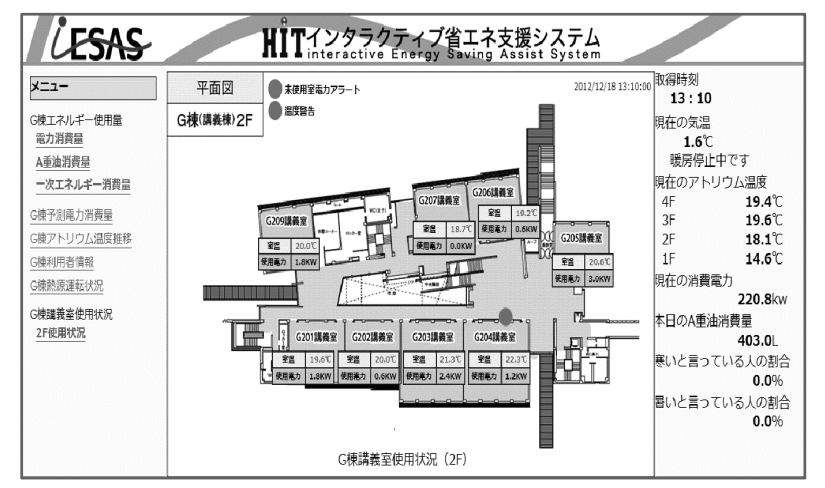

Fig.6 Display screen (room temperature)

3）端末別画面表示機能

(1)グラフ・表の表示 : 電力消費量、重油消費量、一次エネルギー 消費量、予測電力消費量、アトリウム温度、ユーザー温冷感申告 比率、熱源運転状況、講義室利用状況等

(2)オブジェクト情報の表示 : 省エネ活動に関連したトレンド情報 (3)ユーザーコメント表示 : ユーザーからのコメント情報

4) ポップアップ通知機能 : 新着ガイダンスの通知

5）各種条件判定機能

計測データのデータ処理值とユーザー情報設定ファイルの值を照 合し、Web サーバー側のプログラムで条件判定を行い、ポップア ップメニューの表示とガイダンスを配信する。設定ファイルによ り、判定条件を変更することを可能とする。

各種条件判定処理の設定や判定基準値はユーザー情報設定ファイ ルに CSVファイルで記述する。

6）端末情報入力機能（主観評価の取込み） ユーザー登録された施設 (講義棟) 利用者が携帯端末等で入力し た、「暑い」「寒い」などの主観的な温冷感申告や、省エネや環境 に関するコメントを、ユーザーPC やインタラクティブディスプ レイに表示する。また、温冷感情報（申告数）は、データベース に取り込み、各種条件判定に利用寸る。
Table11 Questionnaires about operability

【For students】

(1) Operability from smartphone

(Login count, Thermal sensation information / comment input count, Improvement points)

(2) Overall evaluation of the system

(Effectiveness, Improvement points)

【For faculty staff and administrator】

(1) Guidance mail notification function

(Mail reception amount, Guidance content and action, Effectiveness, Improvement points)

(2) Popup notification function

(Effectiveness, Improvement point)

(3) Reception and transmission of information by smartphone

(Effectiveness to equipment operation management,

Additional items, Improvement points)

(4) Overall evaluation of the system

(Effectiveness, Improvement points)

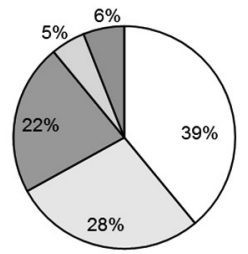

ㅇำㅁㅁ10

Thermal sensation input frequency (student / 2 weeks)

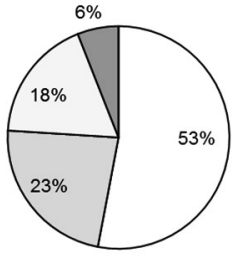

$\square 0 \square 1 \square 3$ 口10

Comment input frequency (student / 2 weeks)
Fig.7 Access frequency during pilot period

\section{3 運用評価}

\section{3. 1 ユーザー評価}

開発した「双方向システム」について、教職員 (10 名)、施設管 理者 (3 名)、学生ボランティア (75 名) をユーザーとして登録し、 4 週間の試験運用とアンケート調查を実施し、使用感の確認およ びログデータ分析による問題点の把握と修正を実施した。アンケ ート内容、アクセス頻度を Table11、Fig.7 に示す。

教職員・学生の携帯端末からの入力操作に問題はなかったが、 「温冷感申告」は「暑い/寒い」の 2 択としたため、学生の $50 \%$ か らは、細かい選択肢があった方が望ましいという回答があった。

施設管理者からは、「ガイダンスのメール数が多く、緊急性が判 断できない」、機器の発停に関するガイダンスには、「室温や機器 の運転状況など具体的な数值があった方が判断しやすい」との回 答があった。システム全体については、「経験的な操作によるもの を、データ情報によって操作できる」、「外気条件や使用者の申告 によって適切に操作できる」、「運転状況をリアルタイムに確認で きる」、「エネルギー消費量の妥当性（適切な運転管理）をチェッ クできる」など省エネルギーに対する有効性を評価する回答であ った。

講義棟ホールに設置したインタラクティブディスプレイは、ス マートフォンでは閲覧できないエネルギー消費状況、各室の室内 環境、温冷感申告の比率を任意の操作で閲覧できるため、80\%の 
ユーザーが、省エネ意識の向上や、現状認識に有効であると評価し た。

\section{3.2 ログデータ分析}

システムの運用状況および問題点を把握するため、一か月間のロ グデータを分析し、ガイダンスメッセージの発報状況を分析した。

試験運用期間のガイダンス発報状況を Fig. 8 に示す。熱源・FCU・ 電力・照明設備に関する条件判定の結果、試験運用開始日の 1 月 8 日には合計 35 件のガイダンス発報があった。ユーザーアンケート にもあるように、ガイダンスが多すぎると緊急性の判断に支障があ るため、プログラムの「情報発信フロー」および判定基準值(閾值)の 修正を行った。

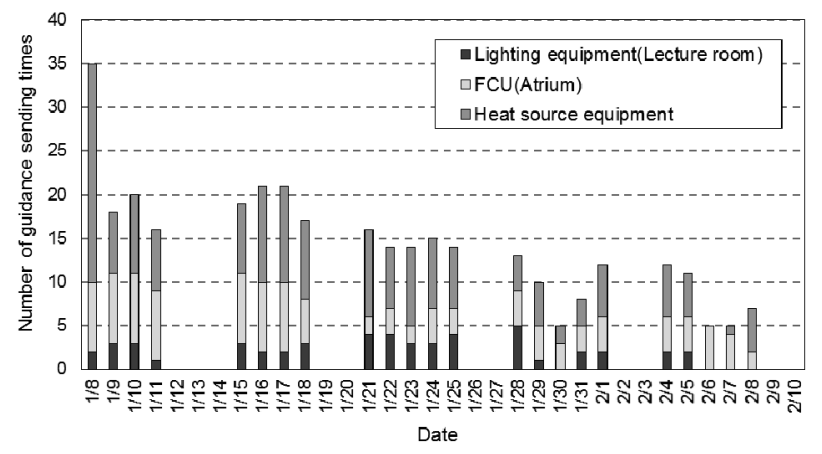

Fig.8 Frequency of occurrence of guidance during pilot period

\section{4 汎用化に向けての課題}

「双方向システム」は、施設利用者、設備運転管理者、施設監理 者が施設の運用状況、各種測定值、利用者の温冷感などの情報を受 発信し、施設、設備の効率的運用を目的として開発した。

また、既存施設などで詳細な計測データが取得しにくい環境下に おいても、利用者の情報を受信することで、不足している情報を補 完し、実際の環境条件に対応した制御、判定が可能となる。

本システムの構成は、標準的な機能部（標準部）と対象施設によ って、設定等を変更する部分（カスタマイズ部）に区分される。他 の施設への導入にあたっては、以下 $(1) \sim(4)$ の項目について、カス タマイズを要する。汎用化を図る上では、対象施設に応じたオペレ ーション項目の絞り込みや情報発信フローの簡略化、判定基準值(閾 值）のチューニング設定の簡易化が課題となる。

1）施設運用モデルの構築（ユースケース分析、省エネルギーオペレ ーション項目の策定、情報発信フローの検討)

2）情報発信の判定に必要な計測ポイントの抽出と計測器の設置お よび計測データの収集システムの導入

3）情報を受発信するユーザー（施設利用者、設備管理者）の設定と 区分

4）ユーザー区分に対応したガイダンスメッセージの作成 本システムは、Web ベースのソフトウェア機能とメールサービス によるガイダンスで構成できるため、現地の計測データを取得し、 そのデータをネットワーク経由でリンク寸ることで、カスタマイズ やチューニング操作を ASP サービスとしても実現することで課題 の解決は可能であると考えられる。

\section{5.まとめ}

本報では、北海道科学大学手稲キャンパスを開発フィールドと して、既設「見える化システム」のデータをもとに、施設のエネ ルギー消費削減可能量の推計手法を示した。さらに、設備の運転 状況や施設の利用状況、屋内外温湿度、利用者の温冷感などの環 境条件をもとに、施設管理者や利用者に省エネルギー行動を促す ことを目的とした双方向ユーザーインターフェース機能を有する 省エネルギー支援システム（「双方向システム」）の開発について 述べた。

得られた知見を以下に示す。

1) 施設のエネルギー消費削減可能量は、対象施設とした「講義棟」 の年間使用記録と時刻別エネルギー消費量の実測值から、照明・ 換気設備の削減可能なエネルギー量として推計した。削減可能 なエネルギー量は、対象施設年間消費電力量の $7.5 \%$ 、空調用燃 料消費量の $2.4 \%$ となり、「双方向システム」の導入によるエネ ルギー削減効果を期待できることを明らかにした。

2)「双方向システム」は、既設「見える化システム」の評価、シス テム導入によるエネルギー消費削減効果の推計および抽出した 省エネルギー対策をもとに、施設運用モデルを構築し、ユーザ ーインターフェースの開発を行なった。

「双方向システム」は、計測データや設備運転状況を取り込み、 設定した判定基準值（閾值）による分析診断機能、ガイダンス メッセージ（メール）の配信などの情報発信機能、利用者の設 備使用状態や温冷感などの情報受信機能を備えたものである。

3)「双方向システム」を、キャンパス内の「講義棟」へ試験導入し、 施設管理者、教職員・学生をモニターとした試験運用を行なっ た。ユーザーによるシステムの有効性・操作性・使用感の評価 から、本システムの有する双方向ユーザーインターフェース機 能が、ユーザーの省エネルギー行動の誘導に有効であることを 明らかにした。

「双方向システム」は、省エネルギー行動の実行を、ガイダン ス配信を受けた設備の運転管理者や施設利用者の判断に委补てい る点を特徴としており、専任の管理者や設備機器の更新、自動制 御設備の導入を必要としない。そのため、あらゆる用途や規模の 建物に導入可能であり、省エネルギー対策が進んでいない建物に おいてもエネルギー消費の削減を実現できるシステムである。

今後は、開発した「双方向システム」を運用し、長期的な操作 性や使用感の確認とシステムの改良を進めるとともに、他用途施 設への展開に向けた課題の抽出と改善を進める予定である。

\section{謝辞}

本報に関わる開発は、国土交通省 平成 $23 \cdot 24$ 年度住宅・建築 関連先導技術開発助成事業『「見える化」を有効活用する設備運用 モデルの策定とユーザーインターフェースの技術開発』として実 施したものです。関係各位に対して記して謝意を表します。

注

注 1）エネルギー消費削減率は、「見える化システム」導入前の 2006 年〜 2008 年度の 3 年間のエネルギー消費量の平均值をベースラインとして 設定して求めた。 
注 2）北海道科学大学では、2009 年の「見える化システム」導入以降、年に 1 回、「省エネルギー意識・行動に関する調査」として、「見える化システ ム」の認知度・利用実態、省エネルギー意識・行動について、大学内の全教 職員・学生を対象としたアンケート調査を実施している。

注 3) 換気用全熱交換器のエンタルピー交換効率は $65 \%$ (カタログスペック) とした。削減可能な換気負荷相当分の燃料消費量は、A 重油燃料発熱量 $39.1 \mathrm{MJ} / \ell$ 、施設の熱源システムの総合効率 $75 \%$ として算出した。

注 4）講義室換気設備については、運転モード（熱交換換気/普通換気）に応 じてガイダンスを配信すべきであるが、機器単体の運転情報をシステムに 取り込めないため、講義終了後の時間帯で照明器具が点灯放置されている 場合、換気設備も稼働したままと判断し、メッセージを送信する設定とし ている。

\section{参考文献}

1) Nagamine, A., et al.: Study on Consumption at four campuses of Toyo University, Journal of Environmental Engineering (Transactions of AIJ), Vol. 75, No. 653, pp. 661-668, 2010.7 (in Japanese) 永峯 章ら: 東洋大学の 4 箇所のキャンパスにおけるエネルギー消費量に 関寸る調査研究, 日本建築学会環境系論文集, 第 75 巻, 第 653 号, pp. 661$668,2010.7$

2) Sung, K.: A Study on the Actual Conditions of Energy Consumption in University Campus with Various HVAC Systems, Journal of SHASE (Transactions of SAHSE), No. 156, pp. 1-9, 2010.3 (in Japanese) 宋 城基: 多様な空調システムが混在する大学キャンパスのエネルギー消 費実態調查研究,空気調和·衛生工学会論文集, 第 156 号, pp. 1-9, 2010.3

3) Takano, C., et al.: Energy Consumption Survey in University Buildings Part2 Utilization Study of Room Lighting and Utility Consideration of Lighting Control in Department of Engineering, Hokkaido University, Summaries of Technical Papers of Annual Meeting, Architectural Institute of Japan, Environmental Engineering, II , pp. 1005-1006, 2011.8 (in Japanese)

高野挑一ら：大学施設におけるエネルギー消費実態の調査研究 その 2 北海道大学工学部における点灯放置の実態と点灯制御の効果, 日本建築学 会大会学術講演梗概集，環境工学 II , pp. 1005-1006, 2011.8

4) Ohashi, T., et al.: Study on Energy Consumption Characteristics of Large-Scale University Facilities, Journal of Environmental Engineering (Transactions of AIJ), Vol. 78, No. 684, pp. 193-201, 2013.2 (in Japanese)

大橋 巧ら：大規模総合大学施設のエネルギー消費実態に関する研究-電力 日負荷曲線の実測データを用いた大阪大学のエネルギー消費特性分析, 日 本建築学会環境系論文集，第 78 巻，第 684 号, pp. 193-201, 2013.2

5) Ohashi, T., et al.: Estimation of Energy End-Use Breakdown in Science Research Facilities, Journal of Environmental Engineering (Transactions of AIJ), Vol. 79, No. 699, pp. 443-450, 2014.5 (in Japanese) 大橋 巧ら：理科系研究施設におけるエネルギー消費内訳の推計, 日本建 築学会環境系論文集, 第 79 巻, 第 699 号, pp. 443-450, 2014.5

6) Kawano, M., et al.: A Study on Reduction Measures of Environmental Load from University Facilities, Journal of Environmental Engineering (Transactions of AIJ), Vol. 76, No. 666, pp. 727-734, 2011.8 (in Japanese)

河野匡志ら：国立大学施設における環境負荷低減手法に関する研究-東京 大学における $\mathrm{CO}_{2}$ 排出量削減に向けた実効ある対策の計画と実践の事例, 日本建築学会環境系論文集, 第 76 巻, 第 666 号, pp. 727-734, 2011.8

7) Kawamura, M., et al.: A Study on Energy Management for Low Carbonization of Multi Existing Buildings Facilities Part1 -Practical Study on Peak Shave and Power Saving at Scientific Faculty, Journal of SHASE (Transactions of SAHSE), No. 241, pp. 21-28, 2017.4 (in Japanese)

河村 貢ら: 多棟の既存建物の低炭素化に向けたエネルギーマネジメント に関する研究 第 1 報 総合大学の理系学部での電力ピーク平準化および節 電実証研究, 空気調和·衛生工学会論文集, 第 241 号, pp.21-28, 2017.4

8) Kawamura, M., et al.: A Study on Energy Management for Low Carbonization of Multi Existing Buildings Facilities Part2 -Practical Study on Peak Shave and Power Saving at a Campus, Journal of SHASE (Transactions of SAHSE), No. 251, pp. 1-8, 2018.2 (in Japanese)

河村 貢ら: 多棟の既存建物の低炭素化に向けたエネルギーマネジメント
に関する研究 第 2 報 総合大学のキャンパスでの電力ピーク平準化およ び節電実証研究, 空気調和·衛生工学会論文集, 第 251 号, pp. 1-8, 2018.2 9) Uozumi, M., Hanzawa, H., Ochiai, S.: Installation of an Energy Monitoring "MIERUKA" System in Campus Buildings, Summaries of Technical Papers of Annual Meeting, Architectural Institute of Japan, Environmental Engineering, II , pp. 1201-1202, 2010.9 (in Japanese) 魚住昌広, 半澤久, 落合総一郎： キャンパス施設における消費エネルギ 一「見える化」システムの構築, 日本建築学会大会学術講演梗概集, 環境 工学 II , pp. 1201-1202, 2010.9

10) Uozumi, M., Hanzawa, H.: Actual Condition Survey on Energy Management and Consumption in Campus Buildings, Summaries of Technical Papers of Annual Meeting, Architectural Institute of Japan, Environmental Engineering, II , pp. 1007-1008, 2011. 8 (in Japanese) 魚住昌広，半澤久：キャンパス施設におけるエネルギー管理・消費に関 わる実態調査, 日本建築学会大会学術講演梗概集, 環境工学 II, pp. 1007-1008, 2011.8

11) Uozumi, M., Hanzawa, H.: Actual Condition Survey on Energy Management and Consumption in Campus Buildings, part2, Reduction of Energy Consumption, Summaries of Technical Papers of Annual Meeting, Architectural Institute of Japan, Environmental Engineering, II , pp. 993-994, 2012.9 (in Japanese)

魚住昌広，半澤久：キャンパス施設におけるエネルギー管理・消費に関 わる実態調査一その 2 エネルギー消費量の削減効果一, 日本建築学会 大会学術講演梗概集, 環境工学 II, pp. 993-994, 2012.9

12) Uozumi, M., Hanzawa, H., Hayama, H.: A Study on The Installation of an Energy Monitoring System in Existing Campus Facilities and Effectiveness of Energy Reduction - Evaluating the effectiveness of the energy monitoring system in Hokkaido University of Science, Journal of Environmental Engineering (Transactions of AIJ), Vol. 83, No. 743, pp. 65-75, 2018.1 (in Japanese)

魚住昌広, 半澤久, 羽山広文: 大学キャンパスの既存施設群におけるエ ネルギーモニタリングシステムの構築とエネルギー削減効果に関する研 究 北海道科学大学における運用評価, 日本建築学会環境系論文集, 第 83 巻, 第 743 号, pp. 65-75, 2018.1 


\author{
Masahiro UOZUMI ${ }^{* 1}$, Hisashi HANZAWA ${ }^{* 2}$ and Hirofumi HAYAMA*3 \\ ${ }^{* 1}$ Assoc. Prof., Faculty of Eng., Hokkaido Univ. of Science \\ ${ }^{*}$ Prof. Emeritus, Faculty of Eng., Hokkaido Univ. of Science, Dr.Eng. \\ ${ }^{* 3}$ Prof., Faculty of Eng., Hokkaido Univ., Dr.Eng.
}

The aim of this study is to show the method of estimating the amount of energy consumed by facilities that can be reduced based on the data of the existing "visualization system" with the campus of "Hokkaido University of Science " as the development field.

In addition, this research describes the development of an energy conservation support system with an interactive user interface function ("Interactive system") aimed at encouraging facility managers and users to conduct energy conservation. The results of the study are as follows:

1) Based on the annual use record and actual measured values of energy consumption by time of the "Lecture Bldg.", the amount that can reduce the consumption energy of the facility was estimated as the amount of energy consumed by lighting equipment and ventilation equipment. The amount of energy that can be reduced is $7.5 \%$ of the annual energy consumption, $2.4 \%$ of the fuel consumption for air conditioning of the "Lecture Bldg.", and it is clear that we can expect the energy reduction effect by introducing the "Interactive system".

2) The development of the "Interactive system" was carried out by the procedure of evaluating the existing "visualization system", estimating the energy consumption reduction effect by introducing the system, extracting the energy conservation measures, building the facility operation model, and creating the user interface. The "Interactive system" has functions of reading measurement data and facility operation status, analyzing / diagnosing functions according to set conditions, sending guidance messages, receiving facility use condition and thermal sensation of users.

3) We introduced the "Interactive System" to the "Lecture Bldg." on the campus, and conducted experiments using facility managers, students, faculty and staff as monitors. From the evaluation of the effectiveness, usability and usability of the system by the user, we clarified that the interactive user interface function of this system is effective for inducing energy saving behavior of users.

"Interactive system" is characterized by entrusting the execution of energy saving behavior to the judgment of the operation manager or facility user of the facility that received the guidance delivery.

It does not require specialized facility managers, renewal of equipment and introduction of automatic control equipment.

Therefore, it is a system that can be installed in buildings of all uses and scales and expected to reduce energy consumption even in buildings where energy saving measures are not progressing.

We will continue to operate the introduced "Interactive system", confirm the operability and feeling of use and improve the system, and work to extract and improve the tasks for developing to other use facilities. 